\title{
Penerapan Hospitalitas Dalam Upaya Menanggulangi Masalah Kemiskinan Di Masyarakat
}

\author{
Marlina Bubang \\ Institut Agama Kristen Negeri Toraja \\ Jalan Poros Makale-Makassar KM 11,5 Buntu Tangti, Mengkendek, \\ Kabupaten Tana Toraja, Sulawesi Selatan 91871 \\ marlinabubang@gmail.com
}

\begin{abstract}
Indonesian is a country that is still classified as a developing country. Indonesian is a also a country that has natural wealth because of its diversity of natural resources. Despite being rich in natural resources, certain Indonesians are still tied to poverty. Poverty is a condition that occurs in society when a person is unable to meet basic needs such as food, education, health, and others. Poverty is caused by an increase in the number of unemployed. The more unemployed, the poverty rate also increases. Unemployment is increasing due to the absence of jobs that can accommodate the workforce so that there is less or even no income to meet primary needs. This will inhibit economic growth in a society. Leaders play an important role in overcoming this provety problem. A leader must have the courage to act, make decisions and dare to take risk. Therefore, the government needs to take action in overcoming provety as a form of hospitality. Hospitality is a form writing by one person to another. Actions taken by the government to show hospitality in overcoming provety such as, providing financial assistance, providing educational facilities, and providing health service facilities.
\end{abstract}

Keyword: povety, unemployment, hospitality, leadership

\begin{abstract}
Abstrak
Indonesia adalah Negara yang masih tergolong Negara berkembang. Negara Indonesia juga merupakan negara yang memiliki kekayaan alam karena keanekaragaman sumber daya alamnya. Meskipun kaya akan sumber daya alam, masyarakat-masyarakat Indonesia tertentu masih terikat dengan kemiskinan. Kemiskinan adalah suatu keadaan yang terjadi dalam masyarakat dimana ketika seseorang tidak mampu untuk memenuhi
\end{abstract}


kebutuhan dasar seperti makanan, pendidikan, kesehatan dan lainnya. kemiskinan disebabkan oleh meningkatnya jumlah pengangguran. Semakin banyak pengangguran akan semakin meningkat angka kemiskinan. Pengangguran semakin meningkat karena tidak adanya lapangan pekerjaan yang dapat menampung tenaga kerja sehingga kurang atau bahkan tidak adanya pendapatan untuk memenuhi kebutuhan primer. Hal ini akan menghambat pertumbuhan ekonomi dalam suatu masyarakat. Pemimpin berperan penting dalam menanggulangi masalah kemiskinan tersebut. Seorang pemimpin harus berani bertindak, mengambil keputusan serta berani mengambil resiko. Oleh karena itu, Pemerintah perlu mengambil tindakan dalam menanggulangi kemiskinan sebagai bentuk hospitalitasnya. Hospitalitas merupakan suatu bentuk keramahan seseorang terhadap oranglain. Tindakan yang dilakukan pemerintah untuk menunjukkan hospitalitas dalam menanggulangi kemiskinan seperti, memberikan bantuan dana, menfasilitasi pendidikan dan memberikan fasilitas pelayanan kesehatan.

Kata kunci: kemiskinan, pengangguran, hospitalitas, kepemimpinan

\section{Pendahuluan}

\section{A. Latar belakang}

Indonesia adalah Negara yang masih tergolong Negara berkembang. Negara Indonesia dapat disebut sebagai Negara memiliki kekayaan alam karena keanekaragaman sumber daya alamnya. Sumber daya alam menjadi penunjang pertumbuhan ekonomi. Karena itu, sumber daya alam berhubungan erat dengan tingkat perekonomian. Meskipun sebuah negara dikatakan negara yang kaya, namun pada kenyataannya negara yang memiliki kekayaan sumber daya alam justru merupakan Negara yang tingkat perekonomiannya rendah. Sehingga masyarakat-masyarakat tertentu tidak terlepas dari kemiskinan.

Kemiskinan merupakan salah satu masalah sosial budaya dalam masyarakat. Pada masa pandemic covid-19 seperti saat ini, angka kemiskinan naik cukup signifikan. Kemiskinan adalah permasalahan yang berdampak buruk terhadap keadaan ekonomi masyarakat. Kemiskinan dapat terjadi disebabkan karena sedikitnya lapangan kerja sehingga sulit bagi masyarakat tertentu untuk mencari 
pekerjaan. Kemiskinan dapat membuat sebagian masyarakat mengorbankan apa saja untuk memenuhi kebutuhan dasar. Selain berdampak kepada perekonomian masyarakat, kemiskinan juga berdampak besar bagi banyaknya anak-anak sehingga tidak bisa melanjutkan pendidikan ke jenjang yang lebih tinggi dan berkualitas.

Salah satu faktor yang mempengaruhi permasalahan kemiskinan adalah meningkatnya pengangguran. Pengangguran semakin meningkat karena tidak adanya lapangan pekerjaan yang dapat menampung tenaga kerja sehingga kurang atau bahkan tidakadanya pendapatan untuk memenuhi kebutuhan dasar. Pengangguran dapat berimbas terhadap ketidakstabilan perekonomian. Meningkatnya pengangguran dalam suatu masyarakat dapat mengakibatkan terjadinya keputusasaan yang bisa menimbulkan depresi bagi masyarakat tertentu. Oleh karena itu, pemimpin serta masyarakat bertanggung jawab untuk segera menanggulangi permasalahan tersebut sebagai wujud hospitalitas. Hospitalitas adalah bentuk keramahan atau kemurahan hati yang diberikan oleh seseorang terhadap oranglain. ${ }^{1}$ Pemimpin adalah seseorang yang mampu memberikan pelayanan yang baik terhadap pimpinannya. Seorang pemimpin perlu menerapkan hospitalitas terhadap masyarakat yang dipimpinnya. Wujud hospitalitas didasarkan pada kasih dan kemurahan hati terhadap seseorang tanpa membeda-bedakan. ${ }^{2}$

\section{B. Rumusan Masalah}

Dari latarbelakang di atas saya dapat merumuskan masalah berikut:

1. Apa itu kemiskinan?

2. Apa itu kepemimpinan?

3. Bagaimana seorang pemimpin menerapkan hospitalitas dalam menanggulangi kemiskinan?

\section{Tujuan}

1. Untuk mengetahui kemiskinan

2. Untuk mengetahui kepemimpinan

\footnotetext{
${ }^{1}$ Michele Hershberger, Hospitalitas Orang Asing: Teman atau Ancaman, (Jakarta: BPK Gunung Mulia, 2009).

2 Daniel Fajar Panuntun dan Eunike Paramita, "Hospitalitas Kristen dan Tantangannya di Tengah Pandemi Covid19", Jurnal Multikultural dan Multireligius, Volume 19, No 1, ( Oktober 2020), 72
} 
3. Untuk mengetahui penerapan hospitalitas pemimpin dalam menanggulangi kemiskinan

\section{Manfaat}

Tulisan ini dapat bermanfaat bagi pembaca untuk belajar bagaimana menjadi pemimpin yang menerapkan hospitalitas dalam dalam menangani masalah-masalah yang terjadi khususnya masalah kemiskinan.

\section{Metode Penelitian}

Tulisan ini menggunakan metode kuantitatif. Dalam penulisan, penulis dapat memahami dan mengembangkan teori melalui kepustakaan.

\section{Pembahasan \\ Latar belakang}

Kemiskinan sudah lama menjadi masalah dunia tetapi persoalan ini masih menjadi hal yang paling berat untuk dihadapi. Kemiskinan adalah suatu masalah yang dihadapi oleh hampir semua Negara-negara termasuk Indonesia. Kemiskinan merupakan salah satu permasalahan yang mendasar dan paling banyak disoroti oleh masyarakat. Masalah ini menjadi pusat perhatian pemerintah khususnya pada masa-masa pandemic covid-19. Kemiskinan didefenisikan sebagai salah satu bentuk dari masalah sosial yang diakibatkan oleh adanya lembaga ekonomi yang tidak berfungsi.

Negara-negara khususnya Indonesia yang merupakan Negara yang memiliki kekayaan alam sudah semakin berkembang. Teknologi saat ini pun sudah semakin berkembang. Tetapi jumlah orang-orang miskin tidak menurun. Dari sisi ekonomi, kemiskinan dipandang sebagai ketidakmampuan dalam memenuhi kebutuhan dasar. Faktor utama penyebab kemiskinan adalah rendahnya tingkat pendidikan dan upah yang rendah. Selain itu kemiskinan juga diakibatkan oleh tingkat pengangguran yang tinggi. Pengangguran merupakan suatu indikator yang menyebabkan Negara Indonesia masih Negara berkembang. Penyebab adanya pengangguran adalah adanya tenaga kerja dan lowongan pekerjaan yang tidak seimbang.

\section{A. Kemiskinan}

\section{Pengertian Kemiskinan}

Kemiskinan merupakan sebuah masalah global. Secara umum, kemiskinan didefenisikan sebagai keadaan kekurangan dana. Kemiskinan merupakan masalah yang terjadi di lingkungan hidup yang disebabkan oleh kurangnya akses 
terhadap pendidikan dan pekerjaan. Dengan kata lain, kemiskinan adalah suatu keadaan yang terjadi dalam masyarakat dimana ketika seseorang tidak mampu untuk memenuhi kebutuhan dasar seperti makanan, pendidikan, kesehatan dan lainnya. Kemiskinan juga dapat terjadi akibat sikap masyarakat yang disebabkan oleh faktor budaya, misalnya seseorang yang malas atau tidak mau berusaha memperbaiki tingkat kehidupan.

Menurut Faisal Bahri, Kemiskinan diartikan sebagai akibat dari ketiadaan demokrasi, yang mencerminkan hubungan kekuasaan yang menghilangkan kemampuan warga suatu Negara untuk memutuskan masalah yang menjadi perhatian mereka sendiri, sehingga mayoritas penduduk kurang memperoleh alat-alat produksi (lahan dan tekonologi) dan sumber daya (pendidikan, kredit, dan akses pasar). ${ }^{3}$

Kemiskinan kadang tidak disadari oleh manusia yang bersangkutan akan kemunculannya sebagai masalah. Bagi sebagian masyarakat yang mengalami kondisi miskin, kemiskinan adalah suatu kehidupan nyata yang mereka jalani sehari-hari karena mereka mengalami hidup tersebut. Namun, meskipun mereka menjalani kehidupan tersebut, terkadang mereka tidak sadar akan kemiskinan yang mereka sedang alami. Kesadaran seseorang akan kemiskinan dapat dirasakan dengan cara membandingkan kehidupan sendiri dengan kehidupan oranglain yang tergolong memiliki tingkat perekonomian yang tinggi.

Dari banyaknya defenisi mengenai kemiskinan sehingga sangat sulit untuk mengukurnya. Menurut Elvis F. Purba, Juliana L Tobing, Dame Esther Hutabarat, kemiskinan dapat di bagi menjadi empat bentuk, yaitu :

1) Kemiskinan absolut adalah suatu konsep yang pengukurannya tidak didasarkan pada garis kemiskinan tetapi pada ketidakmampuan pendapat untuk memenuhi kebutuhan-kebutuhan minimum agar bisa bertahan hidup.

\footnotetext{
${ }^{3}$ Faisal Basri, Perekonomian Indonesia, Tantangan Dan Harapan Bagi Kebangkitan Ekonomi Indoseia (Jakarta : Erlangga, 2002), hlm.9
} 
2) Kemiskinan relatif adalah suatu konsep yang mengacu pada garis kemiskinan(poverty line) yang sebenarnya merupakan suatu ukuran mengenai ketimpangan dalam distribusi pendapatan. Kondisi ini disebabkan pengaruh kebijakan pembangunan yang belum menjangkau seluruh masyarakat,sehingga menyebabkan ketimpangan dalam pendapatan.

3) Kemiskinan kultural adalah suatu konsep yang mengacu pada persoalan sikap seseorang atau masyarakat yang disebabkan oleh faktor budaya.

4) Kemiskinan struktural adalah suatu konsep kemiskinan yang disebebkan karena rendahnya akses terhadap sumber daya. Kemiskinan ini terjadi dalam suatu sistem sosial budaya dan sosial politik yang tidak mendukung pembebasan kemiskinan, tetapi seringkali menyebabkan suburnya kemiskinan. ${ }^{4}$

\section{Faktor Penyebab Kemiskinan}

Kemiskinan umumnya didefenisikan sebagai kekurangan atau ketidakmampuan untuk memenuhi kebutuhan primer. Kemiskinan merupakan masalah yang manusiawi yang dapat dipengaruhi oleh beberapa factor. Di bawah ini beberapa faktor yang menyebabkan timbulnya kemiskinan menurut Hartomo dan Aziz, seperti: 5

1) Malas bekerja

Seseorang yang memiliki sikap malas akan sepenuhnya bersandar pada nasib. Sikap ini akan membuat seseorang tidak memiliki komitmen dalam bekerja.

2) Terbatasnya lapangan kerja

Keterbatasan lapangan kerja sangat mempengaruhi munculnya kemiskinan karena rendahnya bahkan tidakadanya pendapatan. Secara ideal seseorang harus mampu menciptakan lapangan kerja baru sedangkan secara factual hal tersebut sangat kecil kemungkinan bagi masyarakat miskin.

\footnotetext{
${ }^{4}$ Elvis F. Purba dan Juliana L Tobing, Ekonomi Indonesia, (Medan : Universitas HKBP Nommensen 2014), Cet. 2, hlm. 75-76

${ }^{5}$ Ainurrafiqa Pelupessy, “Pengangguran dan Kemiskinan”, https://batukarinfo.com, (diakses 13 Maret 2015)
} 
3) Pendidikan yang terlampau rendah

Pendidikan rendah juga dapat memicu terjadinya kemiskinan karena kurangnya pengetahuan dan keterampilan untuk masuk ke dalam dunia kerja.

4) Keterbatasan Sumber Daya Alam

Masyarakat akan dilanda kemiskinan apabila sumber daya alamnya tidak memberikan keuntungan bagi mereka. Dengan kata lain masyarakat akan miskin karena sumber daya alamnya miskin.

5) Keterbatasan modal

Keterbatasan modal seseorang dapat memicu timbulnya kemiskinan karena seseorang tidak memiliki modal yang cukup untuk melengkapi bahan dalam menerapkan keterampilan sehingga tidak ada penghasilan.

6) Beban keluarga

Kemiskinan juga dapat terjadi ketika anggota keluarga semakin banyak sementara usaha dan pendapatan relatif rendah. Hal ini tidak seimbang karena semakin banyak anggota keluarga akan semakin tinggi tuntutan yang harus dipenuhi.

Kemiskinan juga dapat disebabkan dengan tingginya tingkat pengangguran. Pengangguran adalah golongan angkatan kerja yang belum melakukan suatu pekerjaan yang berpenghasilan. Pengangguran tidak hanya terbatas pada orang yang belum bekerja saja tetapi juga pada orang yang sudah pernah bekerja yang kembali mencari pekerjaan.

Menurut Samuelson dan Nordhaus, pengangguran adalah kelompok yang terdiri dari orang-orang yang tidak bekerja namun masih aktif mencari kerja atau menunggu kesempatan kerja kembali. Agar terhitung sebagai pengangguran, seseorang harus melaporkan usaha spesifiknya dalam mencari 
pekerjaan (seperti melakukan wawancara kerja atau mengirim surat-surat lamaran). ${ }^{6}$

Pengangguran menjadi suatu hal yang sering disoroti oleh suatu masyarakat. pengangguran disebabkan oleh jumlah calon pekerja yang tidak sebanding dengan jumlah lapangan pekerjaan. Selain itu, pengangguran juga dapat disebabkan oleh kemalasan seseorang dalam mencari pekerjaan dan kurangnya komitmen untuk bekerja keras. Menjadi seorang pengangguran bukan hal yang diinginkan tetapi kondisi dan keadaan yang harus memaksa untuk menerima nasib tersebut. berikut beberapa penyebab seseorang mengalami pengangguran:

* Jumlah penduduk relatif banyak sedangkan lapangan kerja relatif rendah.

* pendidikan dan keterampilan rendah

* teknologi yang semakin maju sedangkan kemampuan manusia masih kurang

* adanya pengusaha yang selalu mengejar keuntungan

* lapangan kerja yang dipengaruhi oleh musim seperti pertanian dan perkebunan. $^{7}$

Pengangguran sangat berdampak buruk bagi kehidupan masyarakat dimana hal tersebut mengakibatkan pendapatan masyarakat berkurang sehingga seseorang tidak dapat mencapai tingkat kemakmuran. Pengangguran dapat menimbulkan kekacaual politik dan social di suatu masyarakat yang juga akan menghambat prospek pertumbuhan ekonomi. ${ }^{8}$

\section{Dampak Kemiskinan}

Kemiskinan pada dasarnya disebabkan oleh kurangnya nilai-nilai yang dimiliki oleh seseorang. Nilai-nilai yang dimaksudkan seperti nilai agama, nilai keadilan, nilai kejujuran, nilai dan lain sebagainya. Kurangnya nilai tersebut

\footnotetext{
${ }^{6}$ Paul A. Samuelson dan William D. Nordhaus, Ilmu Makroekonomi, (Jakarta : P.T. Media Global Edukasi, 2004), hlm. 362

${ }^{7}$ Naf'an, Ekonomi Makro, (Yogyakarta : Graha Ilmu, 2014), Cet. 1, hlm 132

${ }^{8}$ I Komang Agus Adi Putra dan Sudarsana Arka, "Analisis Pengaruh Tingkat Pengangguran Terbuka, Kesempatan Kerja, dan Tingkat Pendidikan Terhadap Tingkat Kemiskinan Pada Kabupaten/Kota Di Provinsi bali", Jurnal Ekonomi Pembangunan Universitas Udayana, Volume 7, No 3, ( Maret 2018), 422
} 
dapat mengakibatkan penganiayaan. Baik penganiayaan terhadap diri sendiri maupun penganiayaan terhadap oranglain. ${ }^{9}$

Contoh penganiayaan terhadap diri sendiri dan oranglain:

1) Penganiayaan terhadap diri sendiri

* Tidak punya inisiatif untuk meningkatkan kehidupan yang lebih baik

* Tidak memiliki motivasi

* Kurangnya rencana jangka panjang

Tidak memahami kemiskinan secara tepat

2) Penganiayaan terhadap oranglain

* Orang mampu cenderung tidak peduli terhadap orang yang tidak mampu

* Kebijakan pemerintah yang tidak berpihak kepadanya

\section{B. Kepemimpinan}

Pemimpin adalah seseorang yang memiliki tugas serta sikap yang baik untuk mengarahkan oranglain. Pemimpin juga dapat disebut sebagai orang yang memiliki kemampuan untuk mempengaruhi orang lain agar bekerjasama dengannya untuk mewujudkan sebuah tujuan. Seorang pemimpin harus berani untuk mengambil keputusan resiko. Pemimpin yang baik adalah mereka yang mampu untuk mensejahterakan masyarakatnya.

Kepemimpinan dapat didefenisikan sebagai proses dimana pemimpin mempengaruhi anggotanya untuk mewujudkan visi dan misi. Kepemimpinan merupakan suatu usaha bagaimana menata kinerja agar tercapai keputusan yang diinginkan. ${ }^{10}$ Kepemimpinan adalah suatu proses dimana seseorang memiliki kemampuan untuk mempengaruhi atau mengarahkan oranglain untuk mencapai suatu tujuan tertetu. kepemimpinan juga dapat didefenisikan sebagai relasi antara pemimpin dengan anggota kelompoknya untuk mempengaruhi oranglain agar bekerjasama untuk mencapai tujuan. Harbani mengemukakan pendapatnya bahwa

\footnotetext{
${ }^{9}$ Endang Sulistyowati, “Pemberdayaan Masyarakat Miskin di Pedesaan”, Jurnal Penelitian Ilmu-IImu Sosial, Volume 13, No 1, (2002)

${ }^{10}$ Rensis Linkert, New Patterns Of Management, (New York: Meraw Hill, 1961), hlm. 30
} 
kepemimpinan adalah kemampuan untuk mempengaruhi pihak lain, melalui komunikasi baik langsung maupun tidak langsung dengan maksud untuk menggerakkan orang-orang agar dengan penuh pengertian, kesadaran dan senang hati bersedia mengikuti kehendak pimpinan itu. ${ }^{11}$

\section{Penerapan Hospitalitas Pemimpin Dalam Menanggulangi Kemiskinan Hospitalitas}

Hospitalitas dalam bahasa sehari-hari disebut keramahtamahan. Secara etimologi kata Hospitalitas berasal dari kata hospitality. Kataq ' hospitality berasal dari bahasa Latin "hospes" yang berarti "tuan rumah", dapat juga bermakna "orang asing". Bentuk lain dari kata hospes adalah hostis yang artinya "musuh" sehingga hostility yang artinya "permusuhan". ${ }^{12}$ Hospitalitas adalah sesuatu yang menunjukkan sikap murah hati atau ramah antara satu orang dengan oranglain. Ibarat tuan rumah dan tamu, hospitalitas ditunjukkan dengan cara bagaimana tuan rumah menyambut tamunya dengan ramah atau murah hati. Adanya sikap hati yang ramah untuk menerima oranglain apa adanya. Hikmat Tuhan yang menerima manusia apa adanya untuk mengajarkan manusia untuk hidup dalam dengan hikmat terhadap orang-orang luar(Kol. 4:2). Sebagaimana bahasa Alkitab mengatakan orang-orang yang dulunya orang asing tetapi sekarang dianggap sebagai orang-orang dekat dengan kemurahan Tuhan yang berarti dekat dengan Hospitalitas Allah.

\section{Penerapan Hospitalitas dalam Menanggulangi Kemiskinan}

Penerapan hospitalitas dalam kepemimpinan untuk menanggulangi kemiskinan dapat dilihat bagaimana upaya pemerintah sebagai pemimpin untuk memberikan bantuan kepada masyakat. Seperti pada masa pandemic Covid-19 yang sangat meresahkan masyarakat karena pendapat untuk keberlangsungan hidup sangat minim sekali sehingga tingkat ekonomi masyarakat menjadi sangat rendah.

\footnotetext{
${ }^{11}$ Pasolong Harbani, Kepemimpinan Birokrasi, (Bandung: CV. Alfabeta, 2008), hlm. 5

${ }^{12}$ Selisip, “Hospitalitas”, https://selisip.com, (diakses pada Juli 2018)
} 
Adapun upaya-upaya yang dilakukan pemerintah menanggulangi masalah kemiskinan dalam masyarakat, seperti:

1. Memberikan bantuan dana

Pemerintah memberikan bantuan dana kepada masyarakat yang tergolong kurang mampu. Hal ini sangat membantu masyarakat dalam memenuhi kebutuhan dasar seperti makanan.

2. Memberikan fasilitas pendidikan

Pemerintah juga tidak lupa memberikan bantuan kepada pelajar untuk tetap mengikuti rangkaian dari kegiatan pembelajaran yang dilakukan secara daring seperti bantuan kuota internet.

3. Memberikan fasilitas pelayanan kesehatan

Berbicara tentang kesehatan maka pemerintah akan memperhatikan masyarakat agar dalam masa pandemic ini kesehatan dapat keadaan sehat. Maka, terlebih khusus pemerintah memfasilitasi para tenaga medis agar tetap dapat memberikan pelayanan kepada masyarakat.

\section{Kesimpulan}

Dari pembahasan di atas dapat ditarik kesimpulan bahwa kemiskinan merupaka suatu masalah social budaya yang sudah lama terjadi. Kemiskinan adalah suatu masalah yang disebabkan oleh kurangnya pendapatan untuk memenuhi kebutuhan dasar. Terjadinya kemiskinan tentunya disebabkan oleh beberapa faktor. Faktor mendasar penyebab kemiskinan adalah berkembangnya pengangguran dalam suatu masyarakat. merebaknya tingkat pengangguran karena jumlah angkatan tenang kerja tidak seimbang dengan lapangan pekerjaan. Semakin banyak pengangguran semakin meningkat angka kemiskinan dalam masyarakat. Oleh karena itu, pemerintah sebagai pemimpin masyarakat berupaya untuk menanggulangi masalah tersebut. upaya-upaya yang dilakukan pemerintah untuk menanggulangi masalah tersebut seperti memberikan bantuan dana, menfasilitasi pendidikan, dan memberikan fasilitas pelayanan kesehatan. Hal ini merupakan wujud hospitalitas pemimpin terhadap masyarakat dimana masyarakat menerima secara baik bantuan-bantuan tersebut.

\section{Saran}


Dalam tulisan ini, penulis sangat mengharapkan kesempurnaan dalam penyusunan kata. Tetapi, penulis tidak terlepas dari kekurangan oleh karena pengetahuan yang masih minim sehingga penulis sangat mengharapkan kritik dan saran dari pembaca untuk membantu dalam menyusun karya ilmiah dengan lebih baik.

\section{Referensi}

Hershberger, Michele. Hospitalitas Orang Asing: Teman atau Ancaman. Jakarta: BPK Gunung Mulia, 2009

Panuntun, Daniel Fajar dan Eunike Paramita. "Hospitalitas Kristen dan Tantangannya di Tengah Pandemi Covid-19", Jurnal Multikultural dan Multireligius, Volume 19, No 1, ( Oktober 2020):72

Basri, Faisal. Perekonomian Indonesia, Tantangan Dan Harapan Bagi Kebangkitan Ekonomi Indoseia, Jakarta : Erlangga, 2002

Purba, Elvis F. dan Juliana L Tobing. Ekonomi Indonesia, Cet. 2, Medan : Universitas HKBP Nommensen 2014

Pelupessy, Ainurrafiqa. "Pengangguran dan Kemiskinan". https://batukarinfo.com. (diakses 13 Maret 2015)

Samuelson, Paul A. dan William D. Nordhaus. Ilmu Makroekonomi. Jakarta : P.T. Media Global Edukasi, 2004

Naf'an. Ekonomi Makro. Cet. 1. Yogyakarta : Graha Ilmu, 2014

Putra, I Komang Agus Adi dan Sudarsana Arka. "Analisis Pengaruh Tingkat Pengangguran Terbuka, Kesempatan Kerja, dan Tingkat Pendidikan Terhadap Tingkat Kemiskinan Pada Kabupaten/Kota Di Provinsi bali", Jurnal Ekonomi Pembangunan Universitas Udayana, Volume 7, No 3, ( Maret 2018): 422

Sulistyowati, Endang. "Pemberdayaan Masyarakat Miskin di Pedesaan", Jurnal Penelitian IImu-IImu Sosial, Volume 13, No 1, (2002)

Linkert, Rensis. New Patterns Of Management. New York: Meraw Hill, 1961

Harbani, Pasolong. Kepemimpinan Birokrasi. Bandung: CV. Alfabeta, 2008

Selisip. “Hospitalitas”, https://selisip.com, (diakses pada Juli 2018) 